\title{
Phylogeny and circumscription of Sapindaceae revisited: molecular sequence data, morphology and biogeography support recognition of a new family, Xanthoceraceae
}

\author{
Sven Buerki', Porter P. Lowry II $^{2,3, *}$, Nadir Alvarez ${ }^{4}$, Sylvain G. Razafimandimbison ${ }^{5}$, \\ Philippe Küpfer ${ }^{6}$ \& Martin W. Callmander ${ }^{2,7}$
}

\author{
${ }^{1}$ Department of Biodiversity and Conservation, Real Jardin Botanico, CSIC, Plaza de Murillo 2, ES-28014 Madrid, Spain \\ ${ }^{2}$ Missouri Botanical Garden, P.O. Box 299, St. Louis, MO 63166-0299, U.S.A. \\ ${ }^{3}$ Muséum National d'Histoire Naturelle, Case Postale 39, 57 rue Cuvier, FR-7523105 CEDEX, Paris, France \\ ${ }^{4}$ Department of Ecology and Evolution, Biophore, University of Lausanne, CH-1015 Lausanne, Switzerland \\ ${ }^{5}$ Department of Botany, Bergius Foundation, SE-10691, Stockholm University, Stockholm, Sweden \\ ${ }^{6}$ Institute of Biology, University of Neuchâtel, Rue Emile-Argand 11, CH-2000 Neuchâtel, Switzerland \\ ${ }^{7}$ Conservatoire et Jardin botaniques de la ville de Genève, ch. de l'Impératrice 1, CH-1292 Chambésy, Switzerland \\ *Author for correspondence: pete.lowry@mobot.org
}

\begin{abstract}
Background and aims - Recent studies have adopted a broad definition of Sapindaceae that includes taxa traditionally placed in Aceraceae and Hippocastanaceae, achieving monophyly but yielding a family difficult to characterize and for which no obvious morphological synapomorphy exists. This expanded circumscription was necessitated by the finding that the monotypic, temperate Asian genus Xanthoceras, historically placed in Sapindaceae tribe Harpullieae, is basal within the group. Here we seek to clarify the relationships of Xanthoceras based on phylogenetic analyses using a dataset encompassing nearly $3 / 4$ of sapindaceous genera, comparing the results with information from morphology and biogeography, in particular with respect to the other taxa placed in Harpullieae. We then re-examine the appropriateness of maintaining the current broad, morphologically heterogeneous definition of Sapindaceae and explore the advantages of an alternative family circumscription.

Methods - Using 243 samples representing 104 of the 142 currently recognized genera of Sapindaceae s. lat. (including all in Harpullieae), sequence data were analyzed for nuclear (ITS) and plastid ( $m a t K$, rpoB, $\operatorname{trn} D$-trnT, trnK-matK, $\operatorname{trn} L-\operatorname{trn} F$ and $\operatorname{trnS}$-trnG) markers, adopting the methodology of a recent familywide study, performing single-gene and total evidence analyses based on maximum likelihood (ML) and maximum parsimony (MP) criteria, and applying heuristic searches developed for large datasets, viz. a new strategy implemented in RAxML (for ML) and the parsimony ratchet (for MP). Bootstrap analyses were performed for each method to test for congruence between markers.

Key results - Our findings support earlier suggestions that Harpullieae are polyphyletic: Xanthoceras is confirmed as sister to all other sampled taxa of Sapindaceae s. lat.; the remaining members belong to three other clades within Sapindaceae s. lat., two of which correspond respectively to the groups traditionally treated as Aceraceae and Hippocastanaceae, together forming a clade sister to the largely tropical Sapindaceae s. str., which is monophyletic and morphologically coherent provided Xanthoceras is excluded.

Conclusion - To overcome the difficulties of a broadly circumscribed Sapindaceae, we resurrect the historically recognized temperate families Aceraceae and Hippocastanaceae, and describe a new family, Xanthoceraceae, thus adopting a monophyletic and easily characterized circumscription of Sapindaceae nearly identical to that used for over a century.
\end{abstract}

Key words - Aceraceae, Harpullieae, Hippocastanaceae, molecular phylogeny, new family, Sapindaceae, Xanthoceras, Xanthoceraceae. 


\section{INTRODUCTION}

The systematics of the family Sapindaceae has challenged taxonomists for more than a century since its first comprehensive treatment was published by Radlkofer $(1890,1933)$. Until the late 1980s, Sapindaceae were widely treated as distinct from two closely related families, Hippocastanaceae and Aceraceae, based primarily on morphology and biogeography (Takhtajan 1987, Cronquist 1988, Dahlgren 1989). Several recent studies using pollen morphology (Müller \& Leenhouts 1976), phytochemistry (Umadevi \& Daniel 1991) and molecular sequence data (Gadek et al. 1996, Savolainen et al. 2000, APG II 2003, APG III 2009, Harrington et al. 2005, Buerki et al. 2009) have, however, led to the adoption of a broader concept in an effort to ensure monophyly, uniting these entities into a single family, Sapindaceae s. lat.

Sapindaceae s. lat. as currently circumscribed by Harrington et al. (2005), Thorne \& Reveal (2007) and Buerki et al. $(2009,2010)$ comprise c. 1900 species and 142 genera distributed among four subfamilies: Dodonaeoideae Burnett, Hippocastanoideae Burnett, Sapindoideae Burnett and Xanthoceroideae Thorne \& Reveal. Recently, Buerki et al. (2009) demonstrated the para-/polyphyly of all tribes as defined by Radlkofer (1933), with a single exception, Paullinieae Kunth. Although they sketched an informal system that recognizes a dozen monophyletic groups, they did not propose new tribal limits within the four subfamilies as many potentially important genera of Sapindaceae were not included in their study due to the lack of sequenceable material.

Historically, Radlkofer (1933) recognized fourteen tribes within Sapindaceae s. str., five in Dodonaeoideae and nine in Sapindoideae (see table 1 in Buerki et al. 2009 for details). Within Dodonaeoideae, however, he encountered difficulty assigning nine genera to the four previously described tribes, ultimately deciding to place them in a new tribe, Harpullieae Radlk. Within this heterogeneous assemblage, he recognized two informal groups according to the presence (Delavaya Franchet, Ungnadia Endl. and Xanthoceras Bunge) or absence (Arfeuillea Pierre, Conchopetalum, Eurycorymbus Hand.-Mazz., Harpullia Roxb., Magonia A.St.-Hil. and Majidea J.Kirk ex Oliv.) of a terminal leaflet. While revising Radlkofer's infrafamilial system, largely on the basis of pollen and other morphological features, Müller \& Leenhouts (1976) discussed the possible expansion of Harpullieae to include the three genera comprising Hippocastanaceae, viz. Aesculus L., Billia L. and Handeliodendron (these authors did not, however, comment on the taxonomic status of Aceraceae). In their revised classification, Müller \& Leenhouts (1976) concluded that the connection between Hippocastanaceae and Harpullieae might involve two genera in particular, Handeliodendron, originally described in Sapindaceae (Rehder 1935), and Delavaya, which has always been placed in Sapindaceae. Müller \& Leenhouts (1976) also regarded Harpullieae as a "heterogeneous assemblage", with several genera difficult to connect to the others. For example, they classified Harpullia pollen as both type-A and type-H and Magonia pollen as type-E, whereas other members of the tribe exclusively exhibit the more common type-A pollen (see Buerki et al. 2009 for more details on pollen morphology). Moreover, Harpullieae range from tropical (e.g. Conchopetalum, Delavaya, Magonia) to temperate (Xanthoceras) regions and include both evergreen and deciduous species (Radlkofer 1933, Müller \& Leenhouts 1976). Based on wood anatomy, Klaassen (1999) noted a difference between the temperate and tropical genera in the tribe, and among the tropical ones he indicated that Delavaya and Ungnadia stood out because their wood is similar to that of members of tribe Cupanieae Reichenb. (Sapindoideae). Buerki et al. (2009) found Harpullieae to be polyphyletic, with Xanthoceras occupying a basal position within Sapindaceae s. lat., Arfeuillea, Eurycorymbus, Harpullia and Majidea placed in Dodonaeoideae, Delavaya occupying a basal position within Sapindoideae, and Conchopetalum resolved in the Macphersonia group (Sapindoideae; Buerki et al. 2009) closely related to the newly described endemic Malagasy genus Gereaua Buerki \& Callm. (Buerki et al. 2010). A close relationship between Delavaya and Ungnadia was found in an earlier cladistic analysis based on morphology (Judd et al. 1994), which identified the presence of prolonged basal petal appendages and glabrous stamens as putative synapomorphies, again suggesting that Harpullieae were far from representing a natural assemblage.

In the present study we seek to (1) clarify the relationships of Xanthoceras within Sapindaceae s. lat. and in particular with respect to the other taxa traditionally and/or currently placed in Harpullieae, and (2) re-examine the appropriateness of maintaining the current broadly circumscribed but morphologically heterogeneous definition of Sapindaceae and explore the possible advantages of alternative family circumscriptions. Toward this end, we have significantly expanded the dataset of Buerki et al. (2009) to conduct a new set of phylogenetic analyses, comparing the results with information from morphology and biogeography.

\section{MATERIAL AND METHODS}

\section{Sampling, sequence data and phylogenetic analyses}

Species names, voucher information, and GenBank accession numbers for all sequences are provided in the appendix. The dataset presented in Buerki et al. (2009) was expanded to include a total of 243 samples encompassing more than $70 \%$ of the generic diversity in Sapindaceae s. lat. (104 of the currently recognized 142 genera; half of the 38 genera not included in this analysis are monospecific), representing an increase of ninety ingroup samples and nineteen genera. To assess the phylogenetic relationships of the taxa placed in tribe Harpullieae and in the traditionally recognized families Aceraceae and Hippocastanaceae, we sampled at least one species from each genus currently assigned to these groups by adding the following genera: Magonia and Ungnadia from Harpullieae, plus Billia and Handeliodendron from Hippocastanaceae (Aesculus, the third member of this family, was included in the analysis of Buerki et al. 2009, as were both genera of Aceraceae, Acer and Dipteronia). The outgroup sampling included one taxon each from Anacardiaceae (Sorindeia sp., used as the most external outgroup), Meliaceae (Malleastrum sp.) and Simaroubaceae (Harrisonia abyssinica Oliv.).

The DNA extraction, amplification and sequencing protocols used for the nuclear and plastid regions are provided in Buerki et al. (2009). The nuclear sequences include the whole ITS region (ITS1, 5.8S and ITS2) and plastid markers include 
both coding (matK and rpoB) and non-coding regions (the

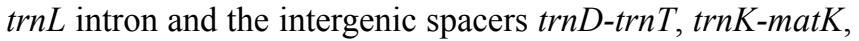
trnL-trnF and $\operatorname{trnS}$-trnG).

Single-gene, total evidence analyses and their corresponding bootstrap analyses were performed using the maximum parsimony (MP) and maximum likelihood (ML) criteria following the same procedure as in Buerki et al. (2009). Parsimony ratchet (Nixon 1999) was performed for each partition and for the combined data set using PAUPRat (Sikes \& Lewis 2001). Ten independent searches were performed with 200 iterations and $15 \%$ of the parsimony informative characters perturbed. A strict consensus tree was constructed based on the shortest equally parsimonious trees. To assess support at each node, non parametric bootstrap analyses (Felsenstein 1985) were performed using PAUP* (Swofford 2002) following the same procedure as in Buerki et al. (2009). Model selection for each partition was assessed using Modeltest v. 3.7 (Posada \& Crandall 1998). ML analyses were performed using RAxML v. 7.0.0 (Stamatakis 2006, Stamatakis et al. 2008) with 1000 rapid bootstrap analyses followed by a search for the best-scoring tree in one single run. These analyses were done using the facilities made available by the CIPRES portal in San Diego, USA (http://8ball. sdsc.edu:8888/cipres-web/home).

Topological differences between single-gene phylogenetic trees were compared by taking into account the level of resolution obtained by each marker and its bootstrap support. Topological differences with bootstrap support (BS) less than $75 \%$ were not considered.

Table 1 - Characteristics of partitions used in the phylogenetic analyses of Sapindaceae s. lat.

IGS = intergenic spacer; MP = maximum parsimony; PI = potentially parsimony informative; $\mathrm{CI}=$ constistency index; RI $=$ retention index; ' for No. of sequences, the total number of samples for the combined analyses is indicated between brackets; ${ }^{2}$ for mean amount of phylogenetic information per sample: averaged by alignment size/variable sites number/PI sites number.

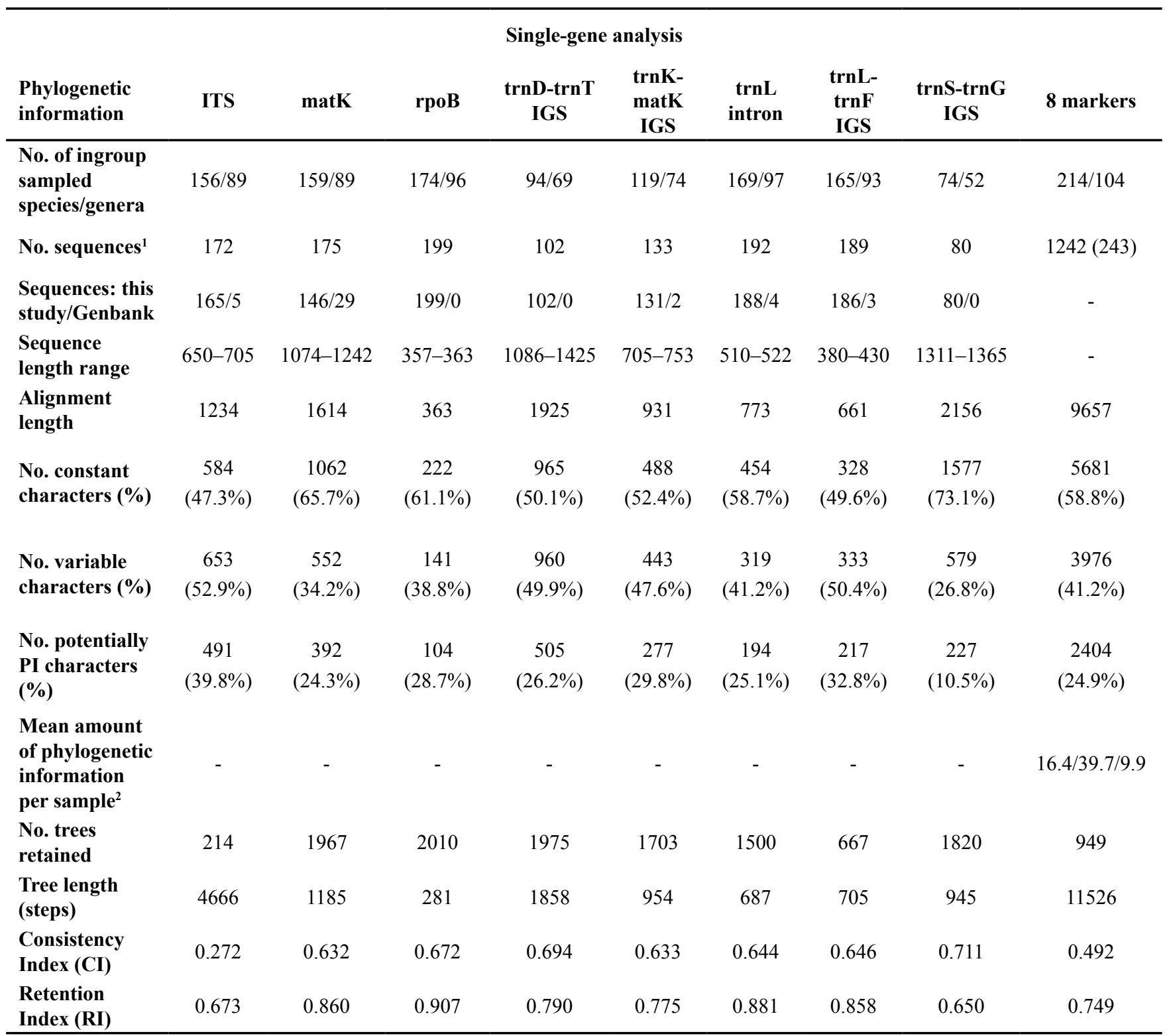


Buerki et al., Recognition of a new family, Xanthoceraceae
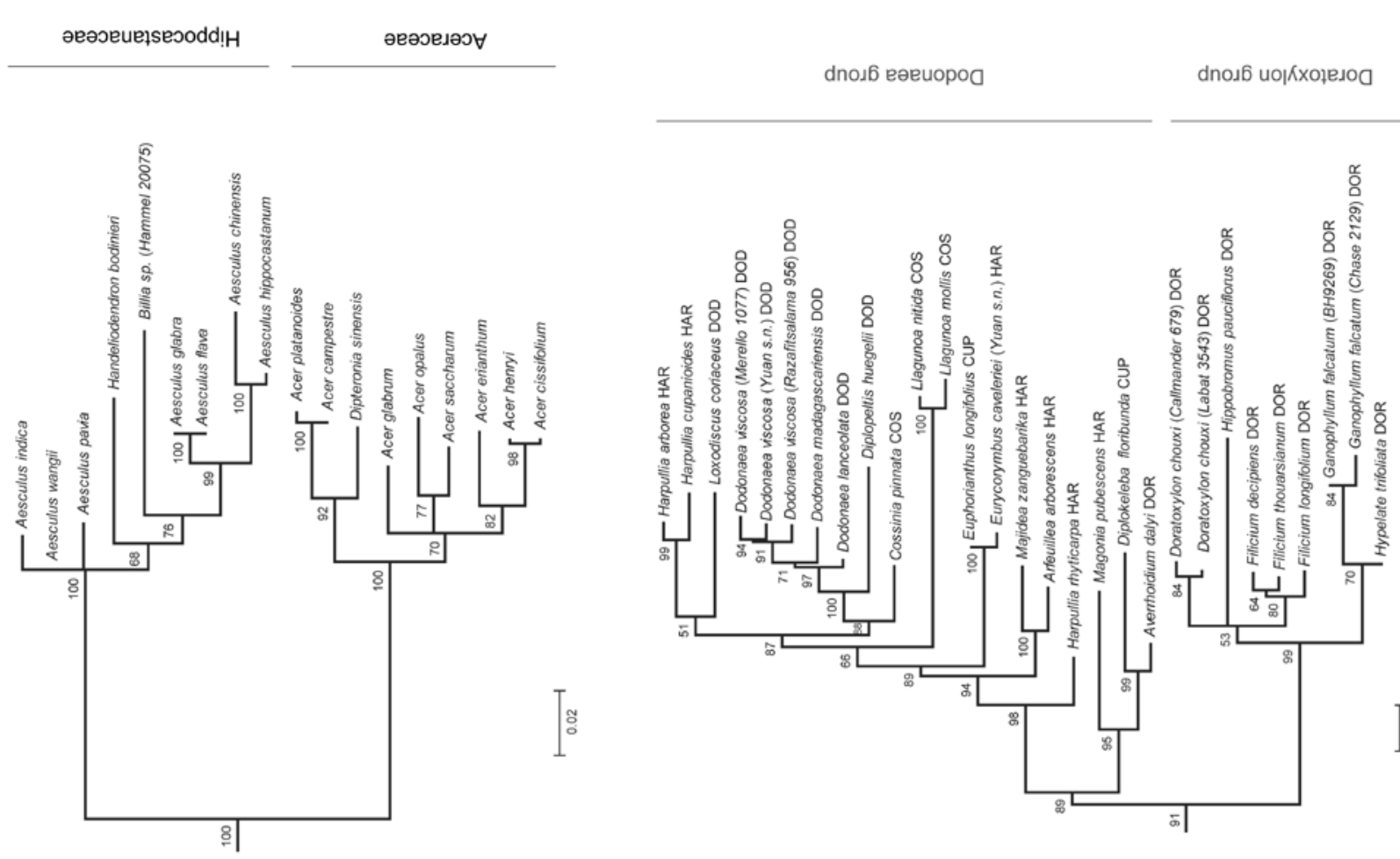

$\infty$

0

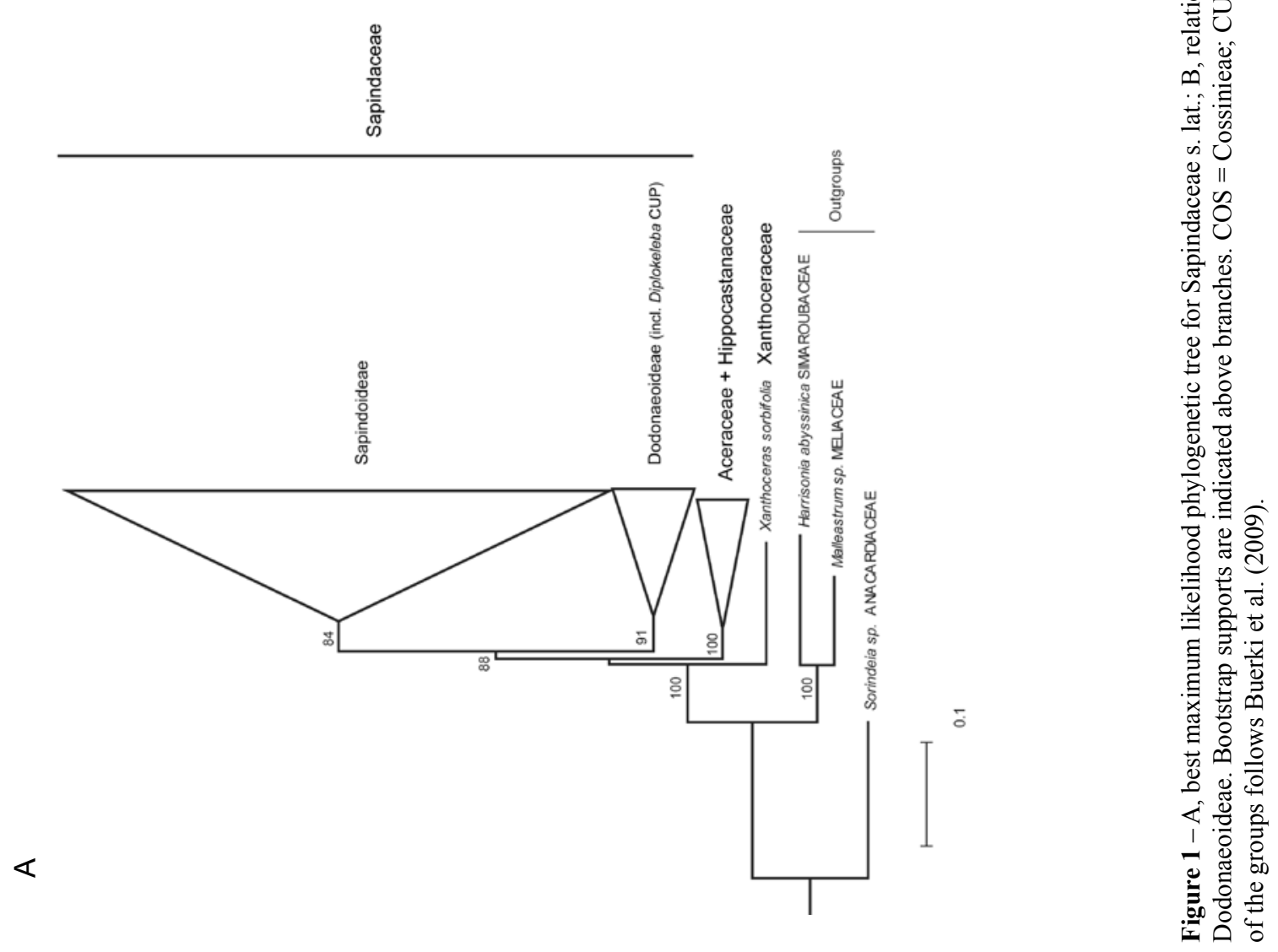




\section{RESULTS}

\section{Alignment and phylogenetic analyses}

The number of samples and statistics for each partition and the combined data set are summarized in table 2 . The best-fit model for all partitions was the general time reversible (GTR) with an alpha parameter for the shape of the gamma distribution to account for among-site rate heterogeneity $(\mathrm{GTR}+\mathrm{G})$. The only exception was the ITS region, in which a proportion of invariable sites was added $(\mathrm{GTR}+\mathrm{G}+\mathrm{I})$. The MP and ML single-gene phylogenies provided different levels of resolution, but no differences with a bootstrap support greater than $75 \%$ were identified when compared, so we combined them in a total evidence approach. Statistics (number of most parsimonious trees; tree length; and consistency and retention indices) for each analysis are reported in table 1 .

For the combined analyses under the MP criterion, nine of the ten independent PAUPrat searches converged on a best score of 11526 steps and produced a total of 949 most parsimonious trees, which were used to compile a strict consensus (not shown); this consensus tree comprised several polytomies, especially near the tips. Under the ML criterion, the best-fit model for the combined matrix was GTR $+\mathrm{G}+\mathrm{I}$. This model was used to perform the single ML run search (log likelihood $=-79995.7$ ), followed by rapid bootstrap analyses.

When compared, analyses compiled under the MP and ML criteria yielded very similar topologies. Moreover, as no moderately to strongly supported differences were observed between the two phylogenetic trees, only the ML topology will be presented and discussed hereafter (figs $1 \& 2$ ).

\section{Phylogenetic relationships}

With the addition of the ninety ingroup samples used in the present analysis, including representatives of several genera of Sapindaceae s. lat. that had not previously been sequenced, the phylogenetic relationships revealed here are highly congruent with the informal system proposed by Buerki et al. (2009). Based on sampling that includes at least one representative of all genera traditionally placed in Sapindaceae tribe Harpullieae, Aceraceae and Hippocastanaceae, our results further confirm that Xanthoceras sorbifolium Bunge (previously assigned to Harpullieae by Radlkofer, 1933) is resolved as sister to the remaining sampled members of Sapindaceae s. lat. (however with a low BS; fig. 1A). Our results also indicate that the other genera of Harpullieae belong to three additional clades, one in subfam. Dodonaeoideae and two in subfam. Sapindoideae (figs $1 \& 2$ ), confirming the polyphyly of the tribe. Within Dodonaeoideae, five of the genera currently assigned to Harpullieae belong to the Dodonaea group, viz. Arfeuillea, Eurycorymbus, Harpullia, Magonia and Majidea (fig. 1C), and Harpullia itself appears to be polyphyletic, with the three species sampled occupying very different positions within the phylogeny (expanded sampling to include additional members of the genus are, however, needed to confirm this finding). Within Sapindoideae, two of the three remaining genera assigned to Harpullieae (Delavaya and Ungnadia) are placed in the Delavaya group, the basal most lineage within the subfamily, and the third genus (Conchopetalum) belongs to the Macphersonia group (fig. 2).

The inclusion of Billia and Handeliodendron in our analysis, along with additional species of Acer and Aesculus, strengthens support for the monophyly of both Aceraceae and Hippocastanaceae and confirms their sister relationship (fig. $1 \mathrm{~A} \& \mathrm{~B}$ ). Our results suggest the possible paraphyly of Acer (with respect to Dipteronia) and of Aesculus (with respect to Billia and Handeliodendron), although this finding should be tested further with additional sampling. Support for the clade comprising Sapindaceae s. str. (i.e. Dodonaeoideae plus Sapindoideae) is likewise stronger in the present analysis (BS $=88$ ) than in that of Buerki et al. (2009; BS = 69; fig. 1). Moreover, Diplokeleba N.E.Br., long regarded as a member of Sapindoideae (tribe Cupanieae), is instead placed within Dodonaeoideae (fig. 1C).

\section{DISCUSSION}

\section{Polyphyly of Harpullieae}

The results presented above clearly show that the tribe Harpullieae (as well as all other sapindaceous tribes with the exception of Paullinieae), as defined initially by Radlkofer (1890, 1933) and modified by Müller \& Leenhouts (1976), is highly polyphyletic, with members placed in no fewer than four clades scattered among various parts of Sapindaceae s. lat. Harrington et al. (2005) and Buerki et al. (2009) argued that additional sampling (especially of Harpullieae) was required before taking a definitive stand regarding the phylogenetic and taxonomic status of Xanthoceras. Although we have now analyzed more than $70 \%$ of the genera and included all those that are putatively related to Xanthoceras, its precise phylogenetic position within Sapindaceae is not strongly supported (BS < 50; fig. 1A). However, both the MP and ML analyses presented here clearly point toward Xanthoceras comprising a basal lineage with Sapindaceae s. lat. (fig. 1A). Moreover, a study comparing the performance of supertree methods based on an identical dataset (Buerki et al. in press) produced the same result, with both the Matrix Representation with Parsimony and MinFlip supertree methods placing Xanthoceras as the most basally branching lineage. This phylogenetic pattern might be explained either by a higher rate of extinction in the lineage that now comprises only Xanthoceras than in the other lineages, or alternatively by a rapid diversification or radiation of these other lineages resulting in a loss of phylogenetic signal (Judd \& Olmstead 2004). In the case of Sapindaceae s. lat., the former hypothesis seems more likely based on preliminary divergence time estimations that place the origin of the clade in the Late Cretaceous (c. $110 \mathrm{My}$ ), with divergence among the four lineages occurring between 90 and 80 My (Buerki et al. in prep.).

The pattern observed here, in which resolution between lineages remains problematic even after sequencing a large number of markers from a broad sampling of taxa, has been observed in many other angiosperm groups, especially among the rosids (Bello et al. 2009 and references within), such as Fabales, where the relationships among the currently accepted families remain unsolved. In order to clarify the situation within Sapindaceae s. lat. and provide a practical classifica- 


\section{Sapindoideae}

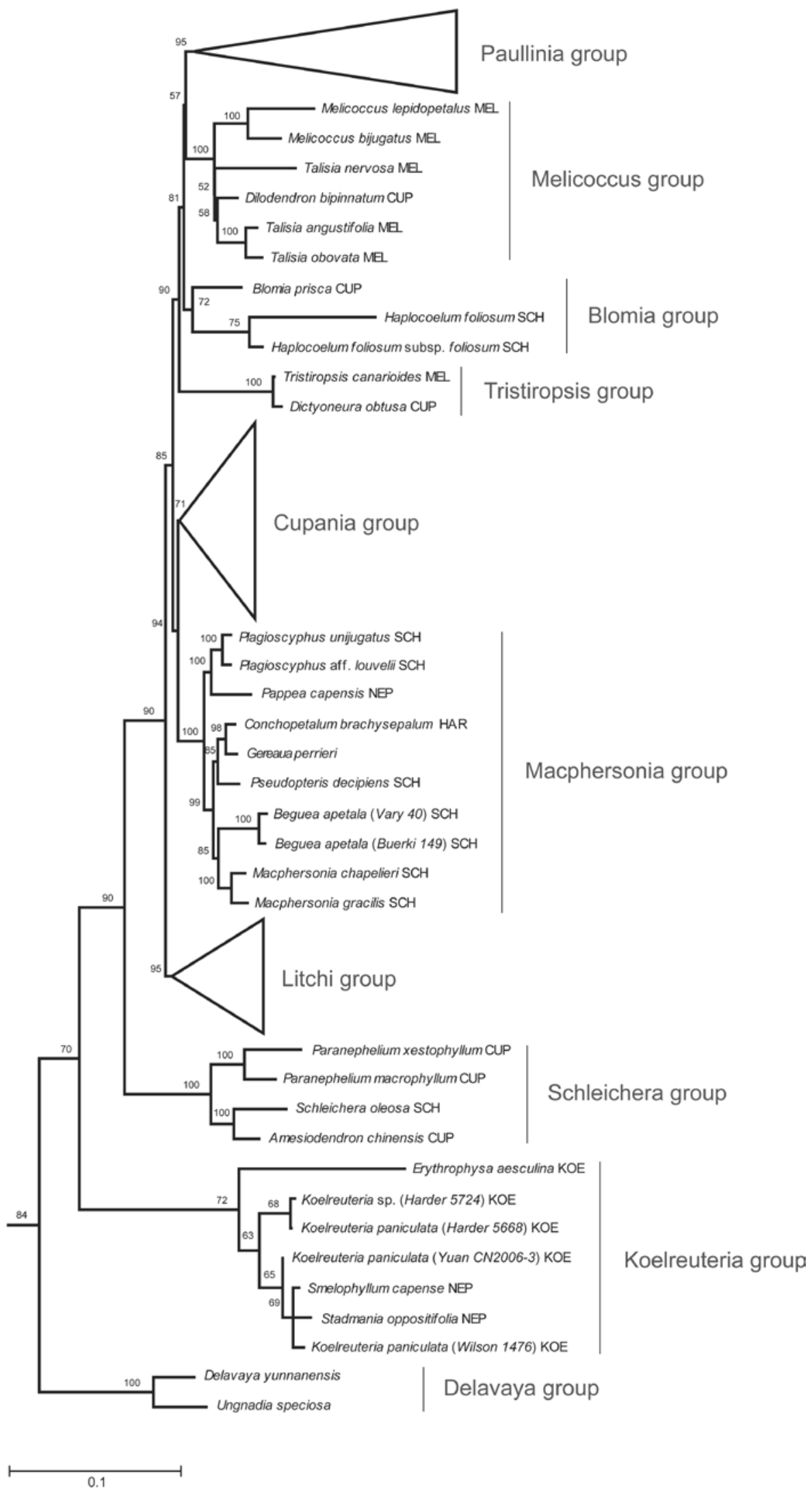

Figure 2 - Relationships within subfamily Sapindoideae. Bootstrap supports are indicated above branches. CUP $=\mathrm{Cupanieae}$; KOE $=$ Koelreuterieae; HAR = Harpullieae; $\mathrm{MEL}=$ Melicocceae; NEP $=$ Nephelieae; $\mathrm{SCH}=$ Schleichereae. The definition of the groups follows Buerki et al. (2009). 
tion that circumscribes easily recognizable groups, we suggest that other criteria should be considered in addition to monophyly. In addition to representing the most basal lineage within the family, Xanthoceras presents a unique and highly distinctive combination of morphological characters, including imparipinnate leaves (vs. paripinnate, evergreen leaves in most genera), large flowers with petals c. $1.5-2 \mathrm{~cm}$ long (vs. small flowers with petals $<1.5 \mathrm{~cm}$ long), 5 -horn-like appendages protruding from the nectary disk (vs. no appendages protruding from the disk), 7-8 ovules per locule (vs. generally 1-2 ovules per locule) and $>15$ seeds (vs. 1-3 seeds). Moreover, if Xanthoceras is included within Sapindaceae s. str., it stands out as the sole member with a north-temperate distribution, whereas all other genera occur in the tropics and/ or subtropics.

The tropical Chinese genus Delavaya, traditionally assigned to Harpullieae, has been viewed by several authors (e.g. Müller \& Leenhouts 1976, Cronquist 1988) as a "link" between Sapindaceae and Hippocastanaceae through the temperate genus Handeliodendron. The molecular analyses presented here failed to confirm this hypothesis (figs $1 \& 2$; see below). Instead, they indicate that Handeliodendron belongs to the Hippocastanaceae clade, a placement previously suggested by Forest et al. (2001) based on the presence of simple, opposite leaves, whereas Delavaya occupies a basal position within subfam. Sapindoideae along with Ungnadia from Texas and Florida, another genus originally assigned to Harpullieae (these two genera thus forming the Delavaya group; fig. 2). As indicated above, a close relationship between Delavaya and Ungnadia was previously suggested by Klaassen (1999) and Judd et al. (1994) based on wood anatomy and morphological cladistic analyses, respectively.

A majority (five out of nine) of the genera traditionally assigned to Harpullieae (viz., Arfeuillea, Eurycorymbus, Harpullia, Magonia and Majidea) belong to subfam. Dodonaeoideae, and in particular to the Dodonaea group, a finding that is consistent with Radlkofer's $(1890,1933)$ original placement of Harpullieae. The basal most branch of the Dodonaea group includes the South American genus Magonia (fig. 1C), associated by Müller \& Leenhouts (1976) with the temperate Asian Xanthoceras on the basis of their sharing seven or eight ovules per locule. The close relationship between Averrhoidium, Diplokeleba (previously assigned to Sapindoideae) and Magonia might be reflected in part by seed morphology; the first two genera are the only members of Sapindaceae to have winged seeds (Radlkofer 1933).

Finally, the results of the phylogenetic analyses presented in this study are in agreement with the findings of Buerki et al. (2009) with regard to the position of the last genus traditionally assigned to Harpullieae, the Malagasy endemic Conchopetalum, which is confirmed to belong to the Macphersonia group (Sapindoideae; fig. 2; see Buerki et al. in press for more details). Relationships between this taxon and other members of Sapindaceae are discussed in Buerki et al. (2009).

Harpullieae have traditionally been considered to represent a "link" between Aceraceae, Hippocastanaceae and Sapindaceae, but as mentioned above, the molecular analyses presented here fail to confirm this hypothesis (figs $1 \& 2$ ). Our analyses do not support the long-held view that Acera- ceae and Sapindaceae are closely related (Radlkofer 1890, 1933, Müller \& Leenhouts 1976, Umadevi \& Daniel 1991). Instead, they show that the two genera currently placed in Aceraceae form a strongly supported group, and that they are more closely related to Hippocastanaceae than to the clade comprising Sapindaceae s. str. (fig. 1B), as earlier suggested by Harrington et al. (2005), Thorne \& Reveal (2007) and Buerki et al. (2009).

The present analyses further confirm that (i) Sapindaceae s. lat. constitute a monophyletic entity that is supported by molecular (but not morphological) synapomorphies; (ii) the three traditionally recognized families Aceraceae, Hippocastanaceae and Sapindaceae, as circumscribed by Radlkofer (1933), are each monophyletic and moderately to strongly supported, provided that Xanthoceras is excluded from Sapindaceae; and (iii) Xanthoceras sorbifolium is sister to the clade comprising these three families (fig. 1A). The concept of a broadly defined Sapindaceae that includes Aceraceae, Hippocastanaceae and Xanthoceras, recently adopted by the Angiosperm Phylogeny Group (APG II 2003) and followed by Harrington et al. (2005), Buerki et al. (2009) and APG III (2009), is consistent with the phylogenetic relationships revealed in earlier studies and confirmed here. However, this broad circumscription of Sapindaceae presents several conceptual problems. First, no clear morphological synapomorphies have been identified for Sapindaceae s. lat. (Harrington et al. 2005, Thorne \& Reveal 2007, Buerki et al. 2009) and the high level of heterogeneity that results from the inclusion of Xanthoceras and the taxa traditionally placed in Aceraceae and Hippocastanaceae makes it difficult to characterize the family. Second, treating Sapindaceae broadly reduces these easily identified and widely recognized families to synonymy, changing the long-established family assignment of several well known, emblematic and widely cultivated genera, most notably Acer and Aesculus.

\section{Classification}

Two alternative approaches are available to address the family level circumscription of the taxa currently placed in Sapindaceae s. lat.: (i) retain the broad definition recently proposed by the Angiosperm Phylogeny Group (APG II 2003, APG III 2009) or (ii) resurrect the temperate families Aceraceae and Hippocastanaceae, restrict Sapindaceae s. str. slightly by excluding Xanthoceras, and describe a new family to accommodate this genus. Both interpretations are consistent with the primary principle of classification as defined by Backlund \& Bremer (1998), which requires the monophyly of taxonomic entities. However, the second approach is clearly preferable when two other principles proposed by these authors are taken into consideration, maximizing ease of identification and maintaining nomenclatural stability. While an argument could be made that it is preferable to avoid adding a new name at the family rank (Stevens 1997), in the present case we believe that this is significantly outweighed by the clear advantages of maintaining Aceraceae, Hippocastanaceae and Sapindaceae (excluding Xanthoceras) as the morphologically and biogeographically coherent entities that have been recognized for well over a century. In order to render Sapindaceae 


\section{Key to distinguish Xanthoceraceae from closely related families}

1. Leaves alternate, compound (rarely unifoliate in some Allophylus and Dodonaea species, both

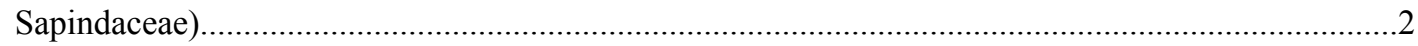

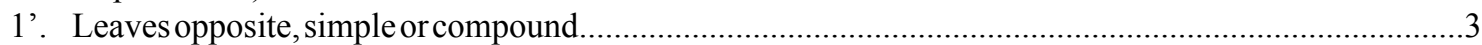

2. Flower large, petals c. $2 \mathrm{~cm}$ long; disc with 5-horn-like appendages; ovules 7 or 8 per locule, all fertile; seeds $>15$ per fruit; leaves imparipinnately compound, plants deciduous; temperate regions of eastern Asia, from inner Mongolia across China to Korea..

Xanthoceraceae

2'. Flower small, petals $<1.5 \mathrm{~cm}$ long; disc lacking horn-like appendages; ovules 1 or 2 per locule ( 7 or 8 in the South American genus Magonia), fertile ovule generally 1 per locule; seeds 1 to 3 per fruit; leaves paripinnately compound (rarely imparipinnate, unifoliolate or simple), plants evergreen; tropical to subtropical regions...

Sapindaceae

3. Flower actinomorphic, leaves palmately lobed or pinnately compound; fruit a schizocarpic fruits with 1 -seeded samaroid mericarps.

..Aceraceae

3'. Flower zygomorphic, leaves palmately compound; fruit a 3-carpellate, usually 1-seeded capsule.

Hippocastanaceae

s. str. monophyletic, we therefore propose to place Xanthoceras in a new monotypic family, Xanthoceraceae.

\section{Taxonomy}

Xanthoceraceae Buerki, Callm. \& Lowry fam. nov. $\equiv$ Sapindaceae subfam. Xanthoceroideae Thorne \& Reveal (Thorne \& Reveal 2007: 119).

Haec familia ab Aceraceis Hippocastanaceis et Sapindaceis flore grandi (petalis c. $2 \mathrm{~cm}$ longis) appendicibus 5 corniformibus e disco nectarifero exsertis, ovulis (omnibus fertilibus) in quoque loculo 6 ad 8 atque seminibus exarillatis plus quam 15 distinguitur. - Type: Xanthoceras sorbifolium Bunge (von Bunge 1833: 85).

Shrubs or small trees, andromonoecious. Leaves imparipinnately compound; leaflets serrate; bracts ovate, large. Flowers in dense racemes $15-20 \mathrm{~cm}$ long, staminate and perfect flowers borne in separate inflorescences, all actinomorphic. Sepals 5, oblong, imbricate. Petals 5, large, c. 2 $\mathrm{cm}$ long, broadly obovate, shortly clawed at base, scale absent. Disk 5-lobed, lobes alternate to petals, apex with five suberect, obtuse, abaxial horn-like appendage. Stamens 8, not exserted; anthers ellipsoid, gland-tipped. Ovary ellipsoid, 3-locular; ovules 7 or 8 per locule, in 2 lines, all fertile; style terminal, erect; stigma papillate. Fruit a globose to pyriform capsule, 3-ridged, pericarp very thick, dehiscing loculicidally into 3 schizocarps. Seeds numerous (>15), compressed-globose, arillode absent. $2 n=30$.

Included genus: Xanthoceras Bunge.

Distribution and habitat - Xanthoceras sorbifolium is widespread in north temperate China, where it grows on hills and slopes in Gansu, Hebei, Henan, Nei Mongol, Ningxia, Shaanxi, Shandong and Shanxi provinces; it is also found in Korea (Xia \& Gadek 2007).

Etymology - Von Bunge (1833) published the name Xanthoceras in reference to the unique yellow horn-like appendages found on the floral disc in the sole member of this genus, $X$. sorbifolium, and coined a common name in English, yel- lowhorn. In Chinese Xanthoceras is referred to as wen guan guo (Xia \& Gadek 2007).

Ethnobotany - Xanthoceras is used as a folk medicine in China for treating various diseases (Chan \& Mak 2006) as well as enuresis in children (Chan et al. 2008). Its seeds are sweet and are prized as a food. Acylated triterpene saponins were recently isolated from the husk of $X$. sorbifolium (Chan et al. 2008) and exhibited cytotoxicity towards several human cancer cell lines (Chan \& Mak 2006).

Notes - The new family Xanthoceraceae can be distinguished from Aceraceae, Hippocastanaceae and Sapindaceae (as recircumscribed here) by a number of morphological features, as summarized in the key presented above.

\section{SUPPLEMENTARY DATA}

Supplementary data are available at Plant Ecology and evolution, Supplementary Data Site (http://www.ingentaconnect. $\mathrm{com} / \mathrm{content} / \mathrm{botbel} / \mathrm{plecevo/supp-data),} \mathrm{and} \mathrm{consist} \mathrm{of} \mathrm{a} \mathrm{tab-}$ ular version of the appendix (pdf format).

\section{ACKNOWLEDGMENTS}

We are grateful to the following persons and institutions for supplying plant material: the Conservatoire et Jardin botaniques de la Ville de Genève (Switzerland); the Malagasy staff of the Missouri Botanical Garden in Antananarivo (Madagascar); Caroline Weckerle (University of Zürich, Switzerland); Laura Vary (University of California-Irvine, USA) and Jean-Noël Labat (Muséum National d'Histoire Naturelle, Paris, France). The first author is also grateful to Yong-Ming Yuan (University of Neuchâtel, Switzerland) for providing laboratory support and plant material. We thank Jérôme Munzinger (Laboratoire de Botanique, Centre IRD de Nouméa, New Caledonia), Roy E. Gereau, Nicholas Turland, Peter B. Phillipson (Missouri Botanical Garden) and Félix Forest (Royal Botanic Gardens, Kew) for valuable discussions and/or specimen identifications. The first author received financial support from the Laboratory of Evolutionary 
Botany (University of Neuchâtel, Switzerland) and a postdoctoral fellowship awarded by the Swiss National Science Foundation ( $\mathrm{n}^{\circ}$ PBNEP3-129903).

\section{REFERENCES}

Angiosperm Phylogeny Group (APG II) (2003) An update of the Angiosperm Phylogeny Group classification for the orders and families of flowering plants: APG II. Botanical Journal of the Linnean Society 141: 399-436.

Angiosperm Phylogeny Group (APG III) (2009) An update of the Angiosperm Phylogeny Group classification for the orders and families of flowering plants: APG III. Botanical Journal of the Linnean Society 161: 105-121.

Backlund A., Bremer, K. (1998) To be or not to be - principles of classification of monotypic families. Taxon 47: 391-400.

Bello M.A., Bruneau A., Forest F., Hawkins J.A. (2009) Elusive relationships within order Fabales: phylogenetic analyses using matK and rbcL sequence data. Systematic Botany 34: 102-114.

Buerki S., Forest F., Acevedo-Rodríguez P., Callmander M.W., Nylander J.A.A.,Harrington M., Sanmartín I., Küpfer P., Alvarez N. (2009) Plastid and nuclear DNA markers reveal intricate relationships at subfamilial and tribal levels in the soapberry family (Sapindaceae). Molecular Phylogenetics and Evolution 51: 238-258.

Buerki S., Phillipson P.B., Lowry II P.P., Callmander M.W. (2010) Molecular phylogenetics and morphological evidence support recognition of Gereaua, a new endemic genus of Sapindaceae from Madagascar. Systematic Botany 35: 172-180.

Buerki S., Forest F., Salamin, N., Alvarez N. (in press) Comparative performance of supertree algorithms in large datasets using the soapberry family (Sapindaceae) as a case study. Systematic Biology.

Chan P.-K., Mak E. (2006) A novel compound isolated from Xanthoceras sorbifolia inhibits ovarian cancer: Identification of diangeloyl groups in saponin essential for anti-tumor activity. Proceedings of the American Association for Cancer Research 47: 452-453.

Chan P.-K., Zhao M., Che C.-T., Mak E. (2008) Cytotoxic acylated triterpene saponins from the husks of Xanthoceras sorbifolia. Journal of Natural Products 71: 1247-1250.

Cronquist A. (1988) The evolution and classification of flowering plants, Ed. 2. New York, New York Botanical Garden Press.

Dahlgren G. (1989) An updated system of classification. Botanical Journal of the Linnean Society 100: 197-203.

Felsenstein J. (1985) Confidence-limits on phylogenies - an approach using the bootstrap. Evolution 39: 783-791.

Forest F., Drouin J. N., Charest R., Brouillet L., Bruneau A. (2001) A morphological phylogenetic analysis of Aesculus L. and Billia Peyr. (Sapindaceae). Canadian Journal of Botany 79: 154169.

Gadek P.A., Fernando E.S., Quinn C.J., Hoot S.B., Terrazas T., Sheahan M.C., Chase M.W. (1996) Sapindales: molecular delimitation and infraordinal groups. American Journal of Botany 83: 802-811.

Harrington M.G., Edwards K.J., Johnson S.A., Chase M.W., Gadek P.A. (2005) Phylogenetic inference in Sapindaceae s. lat. using plastid matK and rbcL DNA sequences. Systematic Botany 30: 366-382.

Judd W.S., Olmstead R.G. (2004) A survey of tricolpate (eudicot) phylogenetic relationships. American Journal of Botany 91: $1627-1644$.
Judd W.S., Sanders R.W., Donoghue M.J. (1994) Angiosperm family pairs: preliminary phylogenetic analyses. Harvard Papers in Botany 5: 1-51.

Klaassen R. (1999) Wood anatomy of the Sapindaceae. International Association of Wood Anatomists Journal 2 (suppl.): 1-214.

Müller J., Leenhouts P.W. (1976) A general survey of pollen types in Sapindaceae in relation to taxonomy. In: Ferguson I.K., Müller J. (eds) The evolutionary significance of the exine: 407445. London, Academic Press.

Nixon K.C. (1999) The Parsimony Ratchet, a new method for rapid parsimony analysis. Cladistics 15: 407-414.

Posada D., Crandall K.A. (1998) Modeltest: testing the model of DNA substitution. Bioinformatics 14: 817-818.

Radlkofer L. (1890) Ueber die Gliederung der Familie der Sapindaceen. Sitzungsberichte der Königl. Bayerischen Akademie der Wissenschaften zu München 20: 105-379.

Radlkofer L. (1933) Sapindaceae. In: Engler A. (ed.) Das Pflanzenreich: Regni Vegetabilis Conspectus (IV) 165 (Heft 98ah). Leipzig, Verlag von Wilhelm Engelmann.

Rehder A. (1935) Handeliodendron, a new genus of the Sapindaceae. Journal of the Arnold Arboretum 16: 65-67.

Savolainen V., Fay M.F., Albach D.C., Backlund A., van der Bank M., Cameron K.M., Johnson S.A., Lledó M.D., Pintaud J.-C., Powell M., Sheahan M.C., Soltis D.E., Soltis P.S., Weston P., Whitten W.M., Wurdack K.J., Chase M.W. (2000) Phylogeny of the eudicots: a newly complete familial analysis based on $\mathrm{rbcL}$ gene sequences. Kew Bulletin 55: 257-309.

Sikes D.S., Lewis P.O. (2001) PAUPRat: PAUP* implementation of the parsimony ratchet. beta software, v. 1. Distributed by the authors. Storrs, Department of Ecology and Evolutionary Biology, University of Connecticut.

Stamatakis A. (2006) RAxML-VI-HPC: Maximum Likelihoodbased phylogenetic analyses with thousands of taxa and mixed models. Bioinformatics 22: 2688-2690.

Stamatakis A., Hoover P., Rougemont J. (2008) A rapid bootstrap algorithm for the RAxML web-servers. Systematic Biology 57: 758-771.

Stevens P.F. (1997) What kind of classification should the practising taxonomist use to be saved? In: Dransfield J., Coode M.J.E., Simpson D.A. (eds) Plant diversity in Malesia III, Proceedings of the third international Flora Malesiana symposium: 295-320. Kew, Royal Botanical Garden.

Swofford D.L. (2002) PAUP*: Phylogenetic analysis using parsimony (*and other methods), v. 4. Sunderland, Massachusetts, Sinauer Associates.

Takhtajan A. (1987) Systema Magnoliophytorum. Leningrad, Soviet Sciences Press.

Thorne R.F., Reveal J.L. (2007) An update classification of the class Magnoliopsida ("Angiospermae"). Botanical Review 73: 67-182.

Umadevi I., Daniel M. (1991) Chemosystematics of the Sapindaceae. Feddes Repertorium 102: 607-612.

von Bunge A.A. (1833) Enumeratio plantarum, quas in China Boreali collegit. Mémoires de l'Académie Impériale des Sciences de Saint Pétersbourg 2: 75-147.

Xia N., Gadek PA. (2007) Sapindaceae. In: Zhengyi W., Raven P.H., Deyuan, H. (eds) Flora of China: 5-24. Beijing, Science Press; St. Louis, Missouri Botanical Garden Press.

Manuscript received 28 Mar. 2010; accepted in revised version 14 Jun. 2010.

Communicating Editor: Steven Dessein. 
Appendix - Voucher information and GenBank accession numbers for taxa used in the phylogenetic analysis of Sapindaceae s. lat. (including outgroups). For each taxon, voucher information (between brackets) is listed in the following order: voucher collector and collection number, institution where the voucher was deposited, country. Accession numbers are listed in the following order: ITS, matK, rpoB, trnD-trnT, trnK-matK, trnL, trnL-F, trnS-trnG. Hyphens indicate that no data are available. The entire table is available as an electronic appendix (see Supplementary Data).

Ingroup: Acer campestre L. (s.n., -, Spain) -, AJ438796, -, -, AJ438796, -, -, -; Acer cissifolium (Siebold \& Zucc.) K.Koch (-, -, -) AF241483, -, -, -, -, -, -, -; Acer erianthum Schwer. (Chase 19983, K, China) EU720501, -, EU720843, EU720980, -, EU721271, EU721459, -; Acer glabrum Torr. (Morris Arb. 93-277B, MO, -) -, -, -, -, -, DQ978532, DQ978532, -; Acer henryi Pax (-, -, -) AF401141, -, -, -, -, -, -, -; Acer opalus Mill. (Grimm GG01305, -, -) AM238317, -, -, -, -, -, -, -; Acer platanoides L. (-, -, -) -, AJ438788, -, -, AJ438788, -, -, -; Acer saccharum Marshall (Chase 106, K, Cult. source, Orange Co.) EU720502, -, EU720844, -, -, EU721272, EU721460, -; Aesculus chinensis Bunge (Xiang 305, -, -) -, AY724267, -, -, -, -, -, -; Aesculus flava Sol. (98-48, -, -) -, AY968670, -, -, -, -, -, -; Aesculus glabra Willd. (J.C. Raulston Accn. No. 960612, -, -) -, AY968671, -, -, -, -, -, -; Aesculus hippocastanum L. (living collection 6911289263, -, -) -, AY724266, -, -, -, -, -, -; Aesculus indica (Wall. ex Cambess.) Hook. (Chase 19987, K, India) EU927392, -, EU720845, EU720981, -, EU721273, EU721461, -; Aesculus pavia Castigl. (Chase 503, K, -) -, -, EU720846, EU720982, -, EU721274, EU721462, -; Aesculus wangii Hu (-, -, -) -, -, -, -, -, AF411085, AF411085, -; Alectryon connatus Radlk. (Chase 2047, K, Australia) EU720415, EU720577, EU720732, EU720928, EU721025, EU721169, EU721357, EU721534; Alectryon coriaceus Radlk. (Edwards KE59, JCT, Australia) -, EU720599, EU720756, -, EU721039, EU721192, EU721380, EU721548; Alectryon excelsus Gaertn. (-, -, -) EF635451, -, -, -, -, -, -, -; Allophyllus arboreus Choux (Rakotovao 2812, MO, Madagascar) EU720508, -, EU720852, -, -, -, -, -; Allophyllus arboreus Choux (Ravelonarivo 1618, MO, Madagascar) EU720515, EU720665, EU720859, -, EU721102, -, -, -; Allophyllus arboreus Choux (Rakotovao 3131, MO, Madagascar) EU720531, EU720681, EU720879, -, EU721118, -, -, -; Allophyllus cobbe (L.) Rauesch (Callmander 462, MO, Madagascar) EU720517, -, EU720861, -, -, -, -, -; Allophyllus longipes Radlk. (-, -, -) -, -, -, -, -, AY207572, AY207572, -; Allophyllus natalensis De Winter (Edwards KE227, JCT, South Africa) -, AY724268, -, -, -, -, -, -; Allophyllus sp. (Edwards KE273, JCT, Tanzania) -, AY724269, -, -, -, -, -, -; Allophyllus trichodesmus Radlk. (Rakotovao 2897, MO, Madagascar) EU720511, -, EU720855, -, -, -, -, -; Allophyllus trichodesmus Radlk. (Ravelonarivo 1619, MO, Madagascar) EU720516, -, EU720860, -, -, -, -, -; Amesiodendron chinensis (Merr.) Hu (Yuan s.n., NEU, China) EU720403, -, EU720718, EU720917, -, EU721155, EU721344, EU721525; Arfeuillea arborescens Pierre (Chase 2122, K, Bogor, BG) EU720461, EU720629, EU720793, EU720962, EU721067, EU721229, EU721417, -; Arytera divaricata F.Muell. (Edwards KE010, JCT, Australia) -, AY724271, -, -, -, -, -, -; Arytera littoralis Blume (Yuan s.n., NEU, China) EU720405, EU720566, EU720720, EU720919, EU721018, EU721157, EU721346, EU721527; Arytera littoralis Blume (Chase 2123, K, Bogor, BG) EU720462, EU720630, EU720794, EU720963, EU721068, EU721230, EU721418, -; Arytera microphylla (Benth.) Radlk. (Edwards KE60, JCT, Australia) -, AY724270, -, -, -, -, -, -; Atalaya alata (Sim) H.Forbes (Edwards KE228, JCT, South Africa) EU720425, EU720593, EU720748, EU720939, EU721036, EU721184, EU721372, EU721543; Atalaya angustifolia S.T.Reynolds (West 5349, ANH, Australia) -, EU720569, EU720723, -, -, EU721160, EU721348, -; Atalaya capense R.A.Dyer (Edwards KE509, JCT, South Africa) EU720429, -, EU720752, -, -, EU721188, EU721376, -; Atalaya salicifolia (DC.) Blume (Edwards KE58, JCT, Australia) -, AY724272, -, -, -, -, -, -; Athyana weinmannifolia (Griseb.) Radlk. (Pennington 17581, MO, Peru) EU720487, EU720649, EU720824, EU720975, EU721086, EU721257, EU721445, EU721576; Averrhoidium dalyi Acev.-Rodr. \& Ferrucci (Weckerle 00/03/18-1/1, Z, Peru) EU720495, -, EU720836, -, -, EU721268, EU721456, -; Beguea apetala Capuron (Buerki 149, NEU, Madagascar) EU720491, EU720652, EU720828, EU720978, EU721089, EU721261, EU721449, -; Beguea apetala Capuron (Vary 40, MO, Madagascar) EU720512, EU720663, EU720856, -, EU721100, EU721281, EU721469, -; Billia sp. (Hammel 20075, -, -) -, AY724275, ,,,,,,$------;$ Blighia sapida K.D.Koenig (Edwards KE86, JCT, West Africa) EU720416, EU720578, EU720733, EU720929, EU721026, EU721170, EU721358, EU721535; Blighia unijugata Baker (Edwards KE274, JCT, Tanzania) -, AY724276, -, -, -, -, -, -; Blomia prisca (Standl.) Lundell (Acevedo 12242, US, Mexico, Yucatán) EU720444, EU720611, EU720772, -, EU721050, EU721208, EU721396, -; Bridgesia incisifolia Bertero ex Cambess. (Killip \& Pisano 39778, K, Chile) EU720476, EU720645, EU720811, EU720973, EU721082, EU721247, EU721435, -; Cardiospermum grandiflorum Sw. (Edwards KE207, JCT, -) -, EU720588, EU720743, EU720935, -, EU721179, EU721367, -; Cardiospermum microcarpum Kunth (Yuan s.n., NEU, China) -, -, EU720712, EU720911, -, EU721149, EU721338, -; Cardiospermum sp. (Yuan s.n., NEU, China) EU720399, -, EU720713, EU720912, -, EU721150, EU721339, -; Castanospora alphandii (F.Muell.) F.Muell. (Edwards KE88, JCT, Australia) -, AY724279, -, -, -, -, -, -; Chytranthus carneus Radlk. (Chase 2868, RBG, -) EU720477, EU720646, EU720812, EU720974, EU721083, EU721248, EU721436, EU721575; Chytranthus prieurianus Baill. (Edwards KE272, JCT, Tanzania) -, AY724280, -, -, -, -, -, -; Conchopetalum brachysepalum Capuron (Rabarimanarivo 8, MO, Madagascar) EU720530, EU720680, EU720877, -, EU721117, EU721299, EU721487, EU721586; Cossinia pinnata Comm. ex Lam. (Lorence 4510, MO, Mauritius) -, -, EU720820, -, -, EU721253, EU721441, -; Cubilia cubili (Blanco) Adelb. (Chase 2125, K, Bogor, BG) EU720463, EU720631, EU720795, EU720964, EU721069, EU721231, EU721419, EU721567; Cupania dentata DC. (Acevedo 12241, US, Mexico, Yucatán) EU720523, EU720670, EU720867, EU720988, EU721107, EU721289, EU721477, EU721581; Cupania guatemalensis (Turcz.) Radlk. (Davidse 35743, MO, Belize) -, EU720678, EU720875, EU720993, EU721115, EU721297, EU721485, -; Cupania hirsuta Radlk. (Acevedo 1101, US, French Guiana) EU720521, EU720668, EU720865, -, EU721105, EU721287, EU721475, -; Cupania rubiginosa (Poir.) Radlk. (Mori 8868, MO, French Guiana) EU720481, -, EU720817, -, -, EU721251, EU721439, -; Cupania scrobiculata Rich. (Acevedo 11100, US, French Guiana) EU720524, EU720671, EU720868, EU720989, EU721108, EU721290, EU721478, -; Cupaniopsis anacardioides Radlk. (Chase 217, K, Australia) EU720438, EU720605, EU720763, EU720946, EU721045, EU721199, EU721387, EU721552; Cupaniopsis flagelliformis (Bailey) Radlk. (Edwards KE42, JCT, Australia) EU720432, EU720598, EU720755, EU720942, -, EU721191, EU721379, EU721547; Cupaniopsis fruticosa Radlk. (Munzinger 564, MO, New Caledonia) EU720533, -, EU720881, -, EU721119, EU721302, EU721490, -; Cupaniopsis sp. (Munzinger 710, MO, New Caledonia) EU720532, -, EU720880, EU720996, -, EU721301, EU721489, EU721587; Cupaniopsis sp. (Munzinger 1103, MO, New Caledonia) EU720507, EU720660, EU720851, -, EU721097, EU721278, EU721466, -; Deinbollia borbonica Scheff. (Edwards KE197, JCT, Tanzania) EU720412, EU720574, EU720729, -, -, EU721166, EU721354, EU721532; Deinbollia macrocarpa Capuron (Antilahimena 4293, MO, Madagascar) -, EU720626, EU720790, -, EU721064, EU721226, EU721414, EU721565; Deinbollia macrocarpa Capuron (H. Razafindraibe 118, MO, Madagascar) EU720535, EU720683, EU720883, -, EU721121, EU721304, EU721492, EU721589; Deinbollia macrocarpa Capuron (Buerki 144, NEU, Madagascar) EU720503, EU720656, EU720847, -, EU721093, EU721275, EU721463, -; Deinbollia oblongifolia (E.Mey. ex Arn.) Radlk. (Edwards KE233, JCT, South Africa) EU720427, EU720595, EU720750, -, -, EU721186, EU721374, EU721545; Deinbollia pervillei (Blume) Radlk. (Phillipson 5919, MO, Madagascar) EU720395, EU720560, EU720708, -, EU721012, EU721145, EU721334, -; Deinbollia pervillei (Blume) Radlk. (Callmander 688, MO, Madagascar) EU720514, -, EU720858, -, -, EU721283, EU721471, -; Delavaya yunnanensis Franch. (Forrest 20682, MO, China, Yunnan) EU720484, -, EU720821, -, -, EU721254, EU721442, -; Diatenopteryx sorbifolia Radlk. (Zardini 43371, MO, Paraguay) EU720534, EU720682, EU720882, -, EU721120, EU721303, EU721491, EU721588; Diatenopteryx sorbifolia Radlk. (Tressens 3504, K, Argentina) -, -, EU720810, -, -, EU721246, EU721434, -; Dictyoneura obtusa Blume (Edwards KE142, JCT, Australia) EU720428, -, EU720751, -, -, EU721187, EU721375, -; Dilodendron bipinnatum Radlk. (Acevedo 11129, US, Bolivia) -, EU720677, EU720874, -, EU721114, EU721296, EU721484, EU721584; Dimocarpus australianus Leenh. (Edwards KE34, JCT, Australia) EU720433, -, EU720757, -, -, , EU721381, -; Dimocarpus longan Lour. (Yuan s.n., NEU, China) -, EU720563, EU720714, EU720913, EU721015, EU721151, EU721340, EU721521; Dimocarpus longan Lour. (Edwards KE502, JCT, Asia) -, EU720590, EU720745, -, -, EU721181, EU721369, -; Dimocarpus longan Lour. (-, -, Thailand) EF532337, -, -, -, -, -, -, -; Dimocarpus longan Lour. (Chase 1351, K, Bogor, BG) -, EU720615, EU720777, EU720953, EU721053, EU721213, EU721401, EU721559; Diploglottis campbelli Cheel (Chase 2048, K, Australian, BG) EU720457, EU720624, EU720788, EU720960, EU721062, EU721224, EU721412, -; Diploglottis diphyllostegia (F.Muell.) Radlk. (Edwards KE001, JCT, Australia) -, AY724287, -, -, -, -, -, -; Mischarytera sp. (Edwards KE159, JCT, Australia) EU720417, EU720579, EU720734, EU720930, EU721027, EU721171, EU721359, -; Diploglottis smithii 
S.T.Reynolds (BG838, BBG, Australia) -, AY724288, -, -, -, -, -, -; Diplokeleba floribunda N.E.Br. (Acevedo 11130, US, Bolivia, St Cruz) -, -, EU720773, EU720950, -, EU721209, EU721397, -; Diplopeltis huegelii Endl. (Chase 2192, K, Australia) EU720473, EU720642, EU720807, EU720971, EU721079, EU721243, EU721431, -; Dipteronia sinensis Oliv. (Chase 502, RBG, -) EU720445, EU720612, EU720774, -, -, EU721210, EU721398, -; Dodonaea lanceolata F.Muell. (Edwards KE120, JCT, Australia) -, AY724290, -, -, -, -, -, -; Dodonaea madagascariensis Radlk. (Bocksberger GB028, NEU, Madagascar) EU720518, -, EU720862, EU720984, -, EU721284, EU721472, -; Dodonaea viscosa Jacq. (Razafitsalama 956, MO, Madagascar) EU720519, EU720666, EU720863, EU720985, EU721103, EU721285, EU721473, -; Dodonaea viscosa Jacq. (Merello 1077, MO, Peru) EU720536, EU720684, EU720884, EU720997, EU721122, EU721305, EU721493, -; Dodonaea viscosa Jacq. (Yuan s.n., NEU, China) EU720406, EU720567, EU720721, EU720920, EU721019, EU721158, EU721347, -; Doratoxylon chouxii Capuron (Labat JNL3543, P, Madagascar) EU720394, EU720559, EU720707, EU720908, EU721011, EU721144, EU721333, -; Doratoxylon chouxii Capuron (Callmander 679, MO, Madagascar) EU720513, EU720664, EU720857, -, EU721101, EU721282, EU721470, -; Elattostachys apetala Radlk. (Munzinger 692, MO, New Caledonia) EU720537, EU720685, EU720885, EU720998, EU721123, EU721306, EU721494, EU721590; Elattostachys apetala Radlk. (McPherson 18184, MO, New Caledonia) EU720538, EU720686, EU720886, EU720999, EU721124, EU721307, EU721495, EU721591; Elattostachys megalantha S.T.Reynolds (Irvine IRV507, CSIRO, Atherton) -, EU720609, EU720768, -, EU721048, EU721204, EU721392, -; Elattostachys microcarpa S.T.Reynolds (Edwards KE98, JCT, Australia) EU720409, EU720571, EU720726, -, -, EU721163, EU721351, -; Elattostachys nervosa (F.Muell.) Radlk. (Chase 2022, K, Australian, BG) EU720455, EU720622, EU720786, EU720959, EU721060, EU721222, EU721410, EU721563; Elattostachys sp. (Lowry 5650A, MO, New Caledonia) EU720529, EU720679, EU720876, EU720994, EU721116, EU721298, EU721486, EU721585; Eriocoelum kerstingii Gilg ex Engl. (Merello 1586, MO, Ghana) EU720539, EU720687, EU720887, EU721000, EU721125, EU721308, EU721496, EU721592; Eriocoelum microspermum Radlk. (Bradley 1025, MO, Gabon) EU720540, EU720688, EU720888, EU721001, EU721126, EU721309, EU721497, EU721593; Erythrophysa aesculina Baill. (Randrianasolo 625, MO, Madagascar) -, -, -, -, -, EU721329, -, -; Euphorianthus longifolius Radlk. (Chase 2126, K, Bogor, BG) EU720464, -, EU720796, -, -, EU721232, EU721420, -; Eurycorymbus cavalerieri (H.Lév.) Rehder \& Hand.-Mazz. (Yuan s.n., NEU, China) EU720404, EU720565, EU720719, EU720918, EU721017, EU721156, EU721345, EU721526; Filicium decipiens (Wight \& Arn.) Thwaites (Chase 2128, K, Bogor, BG) EU720466, EU720633, EU720798, -, -, EU721234, EU721422, -; Filicium longifolium (H.Perrier) Capuron (Rabenantonadro 1113, MO, Madagascar) EU720541, -, EU720889, -, -, EU721310, EU721498, -; Filicium thouarsianum (A.DC.) Capuron (Antilahimena 5021, MO, Madagascar) EU720493, -, EU720832, -, -, EU721265, EU721453, -; Ganophyllum falcatum Blume (Chase 2129, K, Bogor, BG) EU720467, EU720634, EU720799, -, EU721071, EU721235, EU721423, -; Ganophyllum falcatum Blume (BH9269, CSIRO, Australia) -, -, -, -, -, EU721330, -, -; Glenniea pervillei (Baill.) Leenh. (Andriamihajarivo 1053, MO, Madagascar) EU720490, EU720651, EU720827, EU720977, EU721088, EU721260, EU721448, -; Glenniea pervillei (Baill.) Leenh. (Andriamihajarivo 1025, MO, Madagascar) -, EU720653, EU720829, -, EU721090, EU721262, EU721450, -; Gongrodiscus bilocularis H.Turner (Munzinger 749, MO, New Caledonia) EU720542, EU720689, EU720890, -, EU721127, EU721311, EU721499, -; Guindilia trinervis Gilles ex Hook. (Chase 802, K, Chile) -, EU720613, EU720775, EU720951, EU721051, EU721211, EU721399, EU721557; Guioa acutifolia Radlk. (Edwards KE14, JCT, Australia) -, AY724297, -, -, -, -, -, -; Guioa glauca Radlk. (McPherson 18230, MO, New Caledonia) EU720545, EU720692, EU720893, -, EU721130, EU721315, EU721503, -; Guioa lasioneura Radlk. (BG1888, BBG, Australia) -, AY724298, -, -, -, -, -, -; Guioa microsepala Radlk. (Munzinger 744, MO, New Caledonia) EU720546, EU720693, EU720894, -, EU721131, EU721316, EU721504, EU721596; Guioa semiglauca (F.Muell.) Radlk. (Chase 2058, K, Australia, BG) EU720458, EU720625, EU720789, -, EU721063, EU721225, EU721413, -; Guioa villosa Radlk. (McPherson 18040, MO, New Caledonia) EU720544, EU720691, EU720892, EU721003, EU721129, EU721314, EU721502, EU721595; Guioa sp. (Munzinger 945, MO, New Caledonia) EU720505, EU720658, EU720849, -, EU721095, EU721277, EU721465, -; Handeliodendron bodinieri (H.Lév.) Rehder (QYXiang 302 / C. Ming 050923, -, -) -, AY724299, -, -, -, EF186776, -, -; Haplocoelopsis africana F.G.Davies (Edwards KE276, JCT, Tanzania) EU720441, EU720608, EU720767, EU720949, -, EU721203, EU721391, EU721555; Haplocoelum foliosum (Hiern) Bullock (Friis 1894, MO, Ethiopia) EU720479, -, EU720815, -, -, EU721250, EU721438, -; Haplocoelum foliosum subsp. foliosum (Hiern) Bullock (Edwards KE195, JCT, Tanzania) EU720410, EU720572, EU720727, EU720924, -, EU721164, EU721352, EU721530; Haplocoelum gallaense (Engl.) Radlk. (Edwards KE501, JCT, South Africa) -, EU720583, -, -, -, -, -, -; Haplocoelum perrieri Capuron (Rakotomalaza 1165, MO, Madagascar) EU720396, -, EU720709, EU720909, -, EU721146, EU721335, EU721519; Harpullia arborea (Blanco) Radlk. (Chase 1353, K, Bogor, BG) EU720448, -, EU720779, -, -, EU721215, EU721403, -; Harpullia cupanioides Roxb. (-, -, -) AY2075669, -, -, -, -, -, -, -; Harpullia rhyticarpa C.White \& Francis (Edwards KE003, JCT, -) -, AY724303, -, -, -, -, -, -; Hippobromus pauciflorus Radlk. (Edwards KE229, JCT, -) -, AY724305, -, -, -, EU721331, EU721517, -; Hypelate trifoliata Sw. (R. Rankin HABJ72057, K, -) -, -, EU720813, -, -, -, -, -; Jagera javanica (Blume) Blume ex Kalkman (Chase 2130, K, Bogor, BG) EU720468, EU720635, EU720800, -, EU721072, EU721236, EU721424, EU721569; Jagera javanica subsp. australiana Leenh. (Edwards KE178, JCT, Australia) EU720442, -, EU720769, -, -, EU721205, EU721393, EU721556; Jagera pseudorhus var. pseudorhus f. pilosiuscula Radlk. (Edwards KE41, JCT, Australia) -, EU720606, EU720764, EU720947, EU721046, EU721200, EU721388, EU721553; Koelreuteria paniculata Laxm. (Harder 5668, MO, Vietnam) EU720548, EU720695, EU720896, -, EU721133, EU721318, EU721506, -; Koelreuteria paniculata Laxm. (Yuan CN2006-3, NEU, China) EU720397, EU720561, EU720710, -, EU721013, EU721147, EU721336, EU721520; Koelreuteria paniculata Laxm. (Wilson 1476, RBG, -) -, AY724308, -, -, -, -, -, -; Koelreuteria sp. (Harder 5724, MO, Vietnam) EU720547, EU720694, EU720895, EU721004, EU721132, EU721317, EU721505, -; Laccodiscus klaineanus Pierre ex Engl. (Walters 1269, MO, Gabon) EU720549, EU720696, EU720897, -, EU721134, EU721319, EU721507, -; Lecaniodiscus fraxinifolius Baker (Edwards KE194, JCT, Tanzania) EU720418, EU720580, EU720735, EU720931, EU721028, EU721172, EU721360, EU721536; Lepiderema hirsuta S.T.Reynolds (Edwards KE36, JCT, Australia) EU720435, EU720601, EU720759, -, EU721041, EU721195, EU721383, EU721549; Lepiderema pulchella Radlk. (Chase 2020, K, Australian, BG) EU720454, -, EU720785, EU720958, -, EU721221, EU721409, -; Lepidopetalum fructoglabrum Welzen (Edwards KE139, JCT, Australia) EU720408, -, EU720724, EU720922, -, EU721161, EU721349, EU721528; Lepisanthes alata (Blume) Leenh. (Chase 1355, K, Bogor, BG) EU720450, EU720618, EU720781, -, EU721056, EU721217, EU721405, -; Lepisanthes feruginea (Radlk.) Leenh. (Chase 1354, K, Bogor, BG) EU720449, EU720617, EU720780, -, EU721055, EU721216, EU721404, -; Lepisanthes rubiginosa (Roxb.) Leenh. (Chase 1350, K, Bogor, BG) EU720446, EU720614, EU720776, EU720952, EU721052, EU721212, EU721400, EU721558; Lepisanthes senegalensis (Poir.) Leenh. (Callmander 627, MO, Madagascar) EU720492, EU720654, EU720830, EU720979, EU721091, EU721263, EU721451, EU721577; Litchi chinensis Sonn. (Yuan s.n., NEU, China) EU720400, EU720564, EU720715, EU720914, EU721016, EU721152, EU721341, EU721522; Llagunoa mollis Kunth (Jaramillollejia 3199, MO, Colombia) EU720482, -, EU720818, -, -, EU721252, EU721440, -; Llagunoa nitida Ruiz \& Pav. (Pennington 17552, MO, Peru) EU720486, -, EU720823, -, -, EU721256, EU721444, -; Loxodiscus coriaceus Hook.f. (Bradford 1136, MO, New Caledonia) EU720488, -, EU720825, -, -, EU721258, EU721446, -; Macphersonia chapelieri (Baill.) Capuron (Buerki 138, NEU, Madagascar) EU720459, EU720627, EU720791, EU720961, EU721065, EU721227, EU721415, EU721566; Macphersonia gracilis O.Hoffm. (Rabenantoandro 1081, MO, Madagascar) EU720550, EU720697, EU720898, EU721005, EU721135, EU721320, EU721508, EU721597; Magonia pubescens A.St.-Hil. (Mori 16966, MO, Brazil) EU720483, -, EU720819, -, -, -, -, -; Majidea zanguebarika Kirk ex Oliv. (TH275, MO, Madagascar) EU720552, -, EU720900, EU721006, -, EU721322, EU721510, -; Matayba apetala Radlk. (Acevedo 11929, US, Jamaica) EU720526, EU720674, EU720871, -, EU721111, EU721293, EU721481, EU721583; Matayba cf. opaca Radlk. (Acevedo 11118, US, French Guiana) EU720522, EU720669, EU720866, EU720987, EU721106, EU721288, EU721476, EU721580; Matayba domingensis (DC.) Radlk. (Taylor 11819, MO, Caribbean) EU720551, EU720698, EU720899, -, EU721136, EU721321, EU721509, EU721598; Matayba elaeagnoides Radlk. (Zardini 43278, MO, Paraguay) EU720553, EU720699, EU720901, -, EU721137, EU721323, EU721511, -; Matayba guianensis Aubl. (Acevedo 12342, US, French Guiana) EU720527, EU720675, EU720872, -, EU721112, EU721294, EU721482, -; Matayba laevigata Radlk. (Acevedo 12357, US, French Guiana) EU720528, EU720676, EU720873, EU720992, EU721113, EU721295, EU721483, -; Melicoccus bijugatus Jacq. (Acevedo s.n., US, Puerto Rico ) EU927391, EU720610, EU720771, -, EU721049, EU721207, EU721395, -; Melicoccus lepidopetalus 
Buerki et al., Recognition of a new family, Xanthoceraceae

Radlk. (Acevedo 11128, US, Bolivia) EU720443, -, EU720770, -, -, EU721206, EU721394, -; Mischarytera lautereriana (F.M.Bailey) H.Turner (Edwards KE1302, JCT, Australia) -, -, EU720742, -, -, -, -, -; Mischarytera macrobotrys (Merr. \& L.M.Perry) H.Turner (BH6631, CSIRO, Australia) -, AY724313, -, -, -, -, -, -; Mischarytera sp. (Edwards KE159, JCT, Australia) EU720417, EU720579, EU720734, EU720930, EU721027, EU721171, EU721359, -; Mischocarpus exangulatus (F.Muell.) Radlk. (Edwards KE30, JCT, Australia) EU720434, EU720600, EU720758, EU720943, EU721040, EU721194, EU721382, -; Mischocarpus grandissumus Radlk. (Edwards KE37, JCT, Australia) EU720437, EU720604, EU720762, EU720945, EU721044, EU721198, EU721386, EU721551; Mischocarpus pentapetalus (Roxb.) Radlk. (Chase 2133, K, Bogor, BG) EU720470, EU720637, EU720802, EU720966, EU721074, EU721238, EU721426, EU721571; Mischocarpus pyriformis (F.Muell.) Radlk. (Chase 2059, K, Australian, BG) EU720460, EU720628, EU720792, -, EU721066, EU721228, EU721416, -; Molinaea petiolaris Radlk. (Rabenantoandro 1448, MO, Madagascar) EU720554, EU720700, EU720902, EU721007, EU721138, EU721324, EU721512, -; Molinaea sp. nov. (Antilahimena 4301, MO, Madagascar) EU720510, EU720662, EU720854, EU720983, EU721099, EU721280, EU721468, EU721578; Neotina coursii Capuron (H. Razafindraibe 119, MO, Madagascar) EU720543, EU720690, EU720891, EU721002, EU721128, EU721313, EU721501, EU721594; Nephelium lappaceum L. (Edwards KE222, JCT, Asia ) -, EU720584, EU720738, EU720932, EU721030, EU721175, EU721363, EU721537; Nephelium lappaceum L. (Yuan s.n., NEU, China) EU720401, -, EU720716, EU720915, -, EU721153, EU721342, EU721523; Nephelium mutabile Blume (Chase 2134, K, Bogor, BG) -, AY724316, -, -, -, -, -, -; Pancovia golungensis (Hiern) Exell \& Mendonça (Edwards KE231, JCT, Tanzania) EU720411, EU720573, EU720728, EU720925, EU721022, EU721165, EU721353, EU721531; Pappea capensis Eckl. \& Zeyh. (Edwards KE232, JCT, South Africa) EU720424, EU720592, EU720747, EU720938, EU721035, EU721183, EU721371, EU721542; Paranephelium macrophyllum King (Chase 1356, K, Bogor, BG) EU720451, EU720619, EU720782, EU720955, EU721057, EU721218, EU721406, -; Paranephelium xestophyllum Miq. (Edwards KE503, JCT, Asia) EU720420, EU720582, EU720737, -, EU721029, EU721174, EU721362, -; Paullinia alata subsp. alata G.Don (Weckerle 00/03/09-2/1, Z, Peru) -, -, EU720834, -, -, -, -, -; Paullinia elegans Cambess. (Weckerle 00/05/27-1/1, Z, Peru) -, -, EU720835, -, -, EU721267, EU721455, -; Paullinia eriocarpa Triana \& Planch. (Weckerle 00/06/13-1/5, Z, Peru) EU720497, -, EU720839, -, -, -, -, -; Paullinia faginea (Triana \& Planch.) Radlk. (Weckerle 00/05/27-1/5, Z, Peru) -, -, EU720837, -, -, -, -, -; Paullinia faginea (Triana \& Planch.) Radlk. (Weckerle 00/06/13-1/3, Z, Peru) EU720496, -, EU720838, -, -, -, -, -; Paullinia pachycarpa Benth. (Weckerle 01/01/26-1/1, Z, Peru) EU720500, -, EU720842, -, -, -, -, -; Paullinia pinnata L. (Edwards KE199, JCT, Tanzania) EU720413, EU720575, EU720730, EU720926, EU721023, EU721167, EU721355, -; Paullinia subauriculata Radlk. (Weckerle 00/03/19-1/1, Z, Peru) EU720494, -, EU720833, -, -, EU721266, EU721454, -; Plagioscyphus aff. louvelii Danguy \& Choux (Lowry 6034, MO, Madagascar) EU720555, EU720701, EU720903, EU721008, EU721139, EU721325, EU721513, EU721599; Plagioscyphus unijugatus Capuron (Buerki 145, NEU, Madagascar) EU720475, EU720644, EU720809, EU720972, EU721081, EU721245, EU721433, EU721574; Podonephelium homei Radlk. (McPherson 18156, MO, New Caledonia) -, -, -, -, -, EU721312, EU721500, -; Podonephelium homei Radlk. (Pillon 156, MO, New Caledonia) EU720489, EU720650, EU720826, EU720976, EU721087, EU721259, EU721447, -; Pometia pinnata J.R.Forst. \& G.Forst. (Chase 2135, K, Bogor, BG) EU720471, EU720638, EU720803, EU720967, EU721075, EU721239, EU721427, EU721572; Pometia pinnata J.R.Forst. \& G.Forst. (Yuan s.n., NEU, China) EU720402, -, EU720717, EU720916, -, EU721154, EU721343, EU721524; Pseudima sp. (McPherson 15867, MO, Panama) EU720556, EU720702, EU720904, EU721009, EU721140, EU721326, EU721514, EU721600; Pseudopteris decipiens Baill. (Kakazomannjary 12529-SF, MO, Madagascar) EU720480, -, EU720816, -, -, -, -, -; Rhysotoechia mortoniana (F.Muell.) Radlk. (Edwards KE117, JCT, Australia) EU720414, EU720576, EU720731, EU720927, EU721024, EU721168, EU721356, EU721533; Rhysotoechia robertsonii (F.Muell.) Radlk. (Edwards KE277, JCT, Australia) -, EU720570, EU720725, EU720923, EU721021, EU721162, EU721350, EU721529; Sapindus oligophyllus Merr. \& Chun (Yuan s.n., NEU, China) EU720407, EU720568, EU720722, EU720921, EU721020, EU721159, -, -; Sapindus saponaria L. (Chase 2136, K, Bogor, BG) -, EU720639, EU720804, EU720968, EU721076, EU721240, EU721428, -; Sapindus trifoliatus L. (Edwards KE504, JCT, Asia) -, EU720586, EU720740, EU720934, EU721032, EU721177, EU721365, EU721538; Sarcopteryx martyana (F.Muell.) Radlk. (Irvine IRV1810, CSIRO, Australia) EU720426, EU720594, EU720749, EU720940, EU721037, EU721185, EU721373, EU721544; Sarcopteryx reticulata S.T.Reynolds (Gray BG1137, CSIRO, Australia) EU720421, EU720587, EU720741, -, EU721033, EU721178, EU721366, EU721539; Sarcopteryx sp. (Edwards KE49, JCT, Australia) EU720439, EU720607, EU720765, EU720948, EU721047, EU721201, EU721389, EU721554; Sarcotoechia serrata S.T.Reynolds (Edwards KE31, JCT, Australia) EU720436, EU720603, EU720761, EU720944, EU721043, EU721197, EU721385, EU721550; Sarcotoechia villosa S.T.Reynolds (Edwards KE102, JCT, Australia) EU720419, EU720581, EU720736, -, -, EU721173, EU721361, -; Schleichera oleosa (Lour.) Oken (Chase 2137, K, Bogor, BG) EU720423, EU720591, EU720746, EU720937, -, EU721182, EU721370, EU721541; Scyphonichium cf. multiflorum (Mart.) Radlk. (Acevedo 11102, US, French Guiana) -, EU720672, EU720869, EU720990, EU721109, EU721291, EU721479, -; Serjania altissima (Poepp.) Radlk. (Weckerle 00/07/02-1/4, Z, Peru) EU720498, -, EU720840, -, -, EU721269, EU721457, -; Serjania communis Cambess. (Chase 2138, K, Bogor, BG) EU720472, EU720640, EU720805, EU720969, EU721077, EU721241, EU721429, -; Serjania glabrata Kunth (Merello 1058, MO, Peru) EU720557, EU720703, EU720905, EU721010, EU721141, EU721327, EU721515, -; Serjania mexicana (L.) Willd. (Davidse 35748, MO, Belize) -, EU720704, EU720906, -, EU721142, -, -, -; Serjania triquetra Radlk. (-, -, -) AY207571, -, -, -, -, -, -, -; Smelophyllum capense Radlk. (Edwards KE506, JCT, South Africa) -, AY724330, -, -, -, -, -, -; Stadmannia oppositifolia (Lam.) Poir. (Edwards KE505, JCT, Madagascar) -, AY724331, -, -, -, -, -, -; Storthocalyx leioneurus Radlk. (Munzinger 1100, MO, New Caledonia) EU720506, EU720659, EU720850, -, EU721096, -, -, -; Storthocalyx sp. (Munzinger 960, MO, New Caledonia) EU720504, EU720657, EU720848, -, EU721094, EU721276, EU721464, -; Synima cordieri (F.Muell.) Radlk. (Edwards KE29, JCT, Australia) -, EU720602, EU720760, -, EU721042, EU721196, EU721384, -; Synima macrophylla S.T.Reynolds (Edwards KE19, JCT, Australia) EU720430, EU720596, EU720753, EU720941, -, EU721189, EU721377, EU721546; Talisia angustifolia Radlk. (Zardini 43668, MO, Paraguay) EU720558, EU720705, EU720907, -, EU721143, EU721328, EU721516, -; Talisia nervosa Radlk. (Pennington 628, MO, -) EU720474, EU720643, EU720808, -, EU721080, EU721244, EU721432, -; Talisia obovata A.C.Sm. (R. Lombello 13, MO, Brazil) EU720485, EU720648, EU720822, -, EU721085, EU721255, EU721443, -; Thouinia acuminata S.Watson (Liston 633-2, MO, Mexico, Jalisco) EU720478, EU720647, EU720814, -, EU721084, EU721249, EU721437, -; Tina isaloensis Drake (Ranirison PR827, G, Madagascar) EU720520, EU720667, EU720864, EU720986, EU721104, EU721286, EU721474, EU721579; Tina striata Radlk. (Vary 45, MO, Madagascar) EU720509, EU720661, EU720853, -, EU721098, EU721279, EU721467, -; Tinopsis apiculata Radlk. (Buerki 131, NEU, Madagascar) EU720422, EU720589, EU720744, EU720936, EU721034, EU721180, EU721368, EU721540; Toechima daemelianum Radlk. (JC66, CSIRO, Australia) -, AY724334, -, -, -, -, -, -; Toechima erythrocarpum (F.Muell.) Radlk. (Edwards KE20, JCT, Australia) EU720431, EU720597, EU720754, -, EU721038, EU721190, EU721378, -; Toechima plurinerve Radlk. (Chase 1357, K, Bogor, BG) EU720452, EU720620, EU720783, EU720956, EU721058, EU721219, EU721407, EU721561; Toechima tenax (Cunn. ex Benth.) Radlk. (Chase 2046, K, Australian, BG) EU720456, EU720623, EU720787, -, EU721061, EU721223, EU721411, EU721564; Toechima tenax (Cunn. ex Benth.) Radlk. (Chase 2132, K, Bogor, BG) EU720469, EU720636, EU720801, EU720965, EU721073, EU721237, EU721425, EU721570; Tristira triptera (Blanco) Radlk. (Chase 2139, K, Asia) -, EU720585, EU720739, EU720933, EU721031, EU721176, EU721364, -; Tristiropsis acutangula Radlk. (Chase 1358, K, Bogor, BG) EU720453, EU720621, EU720784, EU720957, EU721059, EU721220, EU721408, EU721562; Ungnadia speciosa Endl. (Chase 2854, RBG, -) -, EU720706, -, -, -, EU721332, EU721518, -; Urvillea ulmaceae Kunth (Weckerle 00/07/05-1/1, Z, Peru) EU720499, EU720655, EU720841, -, EU721092, EU721270, EU721458, -; Vouarana guianensis Aubl. (Lucas 109, MO, French Guiana) EU720525, EU720673, EU720870, EU720991, EU721110, EU721292, EU721480, EU721582; Xanthoceras sorbifolium Bunge (Yuan CN2006, NEU, China) EU720398, EU720562, EU720711, EU720910, EU721014, EU721148, EU721337, -; Xerospermum noronhianum (Blume) Blume (Chase 2130, K, Bogor, BG) -, EU720641, EU720806, EU720970, EU721078, EU721242, EU721430, EU721573; Outgroups: Sorindeia sp. (Buerki 137, NEU, Madagascar) -, -, EU720831, -, -, EU721264, EU721452, -; Harrisonia abyssinica Oliv. (Edwards KE510, JCT, Tanzania) EU720440, -, EU720766, -, -, EU721202, EU721390, -; Malleastrum sp. (Rakotovao 2609, MO, Madagascar) -, -, EU720878, EU720995, -, EU721300, EU721488, - 